Article

\title{
CO Tolerance and Stability of Graphene and N-Doped Graphene Supported Pt Anode Electrocatalysts for Polymer Electrolyte Membrane Fuel Cells
}

\author{
Martin González-Hernández ${ }^{1}$, Ermete Antolini ${ }^{2}$ (D) and Joelma Perez ${ }^{1, *}$ \\ 1 São Carlos Institute of Chemistry, University of São Paulo, São Paulo 13560-970, Brazil; caromanto@hotmail.com \\ 2 Scuola di Scienza dei Materiali, Via 25 aprile 22, Cogoleto, 16016 Genova, Italy; ermantol@libero.it \\ * Correspondence: jperez@iqsc.usp.br; Tel.: +55-1633739926
}

Received: 24 April 2020; Accepted: 25 May 2020; Published: 27 May 2020

\begin{abstract}
Pt electrocatalysts supported on pristine graphene nanosheets (GNS) and nitrogen-doped graphene nanoplatelets (N-GNP) were prepared through the ethylene glycol process, and a comparison of their CO tolerance and stability as anode materials in polymer electrolyte membrane fuel cells (PEMFCs) with those of the conventional carbon (C)-supported Pt was made. Repetitive potential cycling in a half cell showed that Pt/GNS catalysts have the highest stability, in terms of the highest sintering resistance (lowest particle growth) and the lowest electrochemically active surface area loss. By tests in PEMFCs, the Pt/N-GNP catalyst showed the highest CO tolerance, while the poisoning resistance of $\mathrm{Pt} / \mathrm{GNS}$ was lower than that of $\mathrm{Pt} / \mathrm{C}$. The higher CO tolerance of $\mathrm{Pt} / \mathrm{N}-\mathrm{GNP}$ than that of $\mathrm{Pt} / \mathrm{GNS}$ was ascribed to the presence of a defect in graphene, generated by N-doping, decreasing $\mathrm{CO}$ adsorption energy.
\end{abstract}

Keywords: PEMFC; CO tolerance; stability; platinum; N-doped graphene nanoplatelets

\section{Introduction}

$\mathrm{Pt} / \mathrm{C}$ is widely used as an anode material in $\mathrm{H}_{2}$-fueled polymer electrolyte membrane fuel cells (PEMFCs). Since $\mathrm{H}_{2}$ is commonly obtained by hydrocarbon reforming, it follows that $\mathrm{CO}$ is present as a contaminant, which is adsorbed on Pt active sites, reducing fuel cell performance [1]. To increase CO tolerance, Pt-based electrocatalysts, especially Pt-Ru and Pt-Mo, are a hopeful solution [1-5].

A major hindrance regarding the utilization of carbon-supported platinum is the poor resistance of carbon surface to be oxidized, resulting in Pt surface area loss, owing to both Pt coalescence and Pt way out from the carbon support [6-8]. Moreover, carbon black has no effect on CO tolerance of Pt. Thus, materials other than carbon black that improve $\mathrm{CO}$ tolerance of $\mathrm{Pt}$ and with higher structural stability and higher resistance to carbon surface oxidation were investigated as Pt supports [9-12]. Tests in fuel cells indicated that graphene nanosheets (GNS) are a suitable PEMFC catalyst support [12]. Especially, nitrogen-doped graphene proved promising for their use in PEMFCs $[13,14]$.

The stability of Pt supported on N-functionalized-graphene was assessed by different theoretical works [15-19]. By density functional theory (DFT) analysis it was found that graphene N-doping improves the binding energy of platinum to the substrate: the binding energy increased by two-fold, resulting in an enhancement of platinum stability [15]. N-doping gives rise to the formation of localized defects near to the Fermi level of graphene, stabilizing Pt atoms. Nitrogen atoms presence into carbon lattice gives rise to three main kinds of nitrogen functional groups, namely, pyridinic $\mathrm{N}$, pyrrolic $\mathrm{N}$, and graphitic $\mathrm{N}$ species [16]. Among these $\mathrm{N}$ species, the more effective at binding Pt are pyridinic $\mathrm{N}$ and pyrrolic $\mathrm{N}$ species [17,18]. 
DFT analysis showed that ripening of Pt particle supported on highly oriented pyrolytic graphite (HOPG) with agglomerated vacancies is highly energetically favorable, while ripening Pt particles on HOPG with pyridinic $\mathrm{N}$ and pyrrolic $\mathrm{N}$ is hindered [18]. The theoretical higher stability of $\mathrm{N}$-doped graphene than pristine graphene was confirmed by experimental results [20]: the retention of the electrochemically active surface area (ECSA) following repetitive potential cycling of N-doped reduced graphene oxide was higher than that of undoped reduced graphene oxide.

Moreover, theoretical works showed that nitrogen doping in graphene enhances $\mathrm{CO}$ tolerance of Pt nanoparticles [21-24]. First, by DFT calculations Tang et al. [21] compared the CO oxidation on $\mathrm{Pt}$ single atoms on pristine and defective graphene: unlike $\mathrm{CO}$ oxidation on $\mathrm{Pt} /$ pristine-graphene, the Pt/defective-graphene showed high activity for $\mathrm{CO}$ oxidation. Defects can be introduced in graphene by $\mathrm{N}$-doping. Kim et al. [22] observed that the binding energy of Pt nanoparticles on $\mathrm{N}$ defects is about three times larger than on pristine graphene. They found that the adsorption energy $\varepsilon_{\mathrm{ad}}$ of $\mathrm{H}_{2}$ and $\mathrm{CO}$ on Pt nanoparticles are not correlated, but the difference in $\varepsilon_{\text {ad }}$ between $\mathrm{H}_{2}$ and $\mathrm{CO}, \Delta \varepsilon_{\text {ad }}=\left(\varepsilon \mathrm{CO}-\varepsilon \mathrm{H}_{2}\right)$, is relatively well correlated to the average energy of $d$ electrons ( $d$-band center) of surface Pt atoms $\left(\varepsilon_{\mathrm{dc}}\right)$ of Pt clusters. As low is $\Delta \varepsilon_{\text {ad }}$ between $\mathrm{CO}$ and $\mathrm{H}_{2}$, as high is $\mathrm{CO}$ tolerance. Because $\mathrm{CO}$ has stronger electron affinity than $\mathrm{H}_{2}$, which indicates a larger amount of electron back donation from $\mathrm{Pt}, \mathrm{CO}$ adsorption is more sensitive to the $\mathrm{Pt} d$-band profile than $\mathrm{H}_{2}$ adsorption. The strong binding of $\mathrm{Pt}$ to $\mathrm{N}$-doped graphene lowers $\varepsilon_{\mathrm{dc}}$ and thus reduces $\Delta \mathrm{E}_{\mathrm{ad}}$. Regarding the role of $\mathrm{N}$ configurations, it was found that the activation barrier for the $\mathrm{O}_{2}$ adsorption is much higher on both the pyridinic nitrogen site and the nearest carbon atom than on graphitic nitrogen sites, while pyridinic nitrogen weakens the $\mathrm{O}-\mathrm{O}$ bond [23]. Both the reaction thermodynamics and kinetics suggest that $\mathrm{CO}$ oxidation over PtN3 would proceed through the Langmuir-Hinshelwood mechanism [19].

Various experimental works were addressed to the evaluation of $\mathrm{CO}$ tolerance of graphene or $\mathrm{N}$-doped graphene-supported catalysts either directly during $\mathrm{H}_{2}$ oxidation in the presence of $\mathrm{CO}$ [25-27], or indirectly during methanol oxidation ( $\mathrm{CO}$ as an intermediate species formed during the methanol oxidation reaction) [28-32]. Hydrogen oxidation in the presence of $\mathrm{CO}$ was carried out only on one type of graphene as the catalyst support, either pristine [25,26] or N-doped [27], and the positive effect of graphene on CO tolerance was ascribed to the formation of sub-nano Pt particles in pristine graphene-supported Pt or to the presence of $\mathrm{N}$ groups in $\mathrm{N}$-doped graphene-supported Pt. Conversely, the poisoning tolerance during the methanol oxidation of $\mathrm{Pt}$ supported on pristine and $\mathrm{N}$-doped graphene was compared in different works [28-32]: the ratio of the forward anodic peak current $\left(\mathrm{I}_{\mathrm{f}}\right)$ to the reverse anodic peak current $\left(\mathrm{I}_{\mathrm{b}}\right)$ is commonly used to evaluate the catalyst tolerance toward the intermediate poisoning carbonaceous species (particularly CO but also other oxygenated species). A higher ratio of $\mathrm{I}_{\mathrm{f}} / \mathrm{I}_{\mathrm{b}}$ indicates the less accumulation of poisoning species on the $\mathrm{Pt}$ nanoparticles, suggesting better $\mathrm{CO}$ tolerance. A higher poisoning tolerance during methanol oxidation of Pt-supported $\mathrm{N}$-doped graphene than that of Pt-supported pristine graphene was observed by Cogenly and Yurtcan [28], Liu et al. [29], and Tao et al. [30], whereas circa the same and a lower poisoning tolerance of Pt/N-GNS than that of Pt/GNS was observed by Ma et al. [31] and Xin et al. [32], respectively.

The majority of previous works dealing on the problem of the poisoning of the $\mathrm{Pt} / \mathrm{C}$ anode catalyst in PEMFCs by the $\mathrm{CO}$ presence in the fuel were addressed to the effect of the addition of a second metal to $\mathrm{Pt}$ on $\mathrm{CO}$ tolerance [1,4]. CO desorption is facilitated by the second metal, either through the electronic effect or the bifunctional mechanism. A modification of the electronic structure of Pt by alloying with a transition metal reduces the $\mathrm{CO}$ adsorption energy and favors the $\mathrm{H}_{2}$ adsorption on $\mathrm{Pt}$ active sites. According to the bifunctional mechanism, the second metal is able to activate $\mathrm{H}_{2} \mathrm{O}$ at low potentials than $\mathrm{Pt}$, facilitating the oxidation of adsorbed CO by supplying oxygen atoms at an adjacent site. In this work, instead, we evaluated the effect of the support on CO tolerance of pure Pt. For the first time an experimental comparison of the $\mathrm{CO}$ tolerance of pristine and $\mathrm{N}$-doped graphene was carried out. Thus, to assess the influence of $\mathrm{N}$-doping 
on the $\mathrm{CO}$ tolerance of $\mathrm{Pt}$ supported on both on pristine and $\mathrm{N}$-functionalized graphene, we prepared GNS and nitrogen-doped graphene nanoplatelets (N-GNPs)-supported Pt catalysts, and compared the performance of PEMFCs with these anode catalysts in the presence and in the absence of $\mathrm{CO}$ with each other and with that of a PEMFC with conventional Pt/C.

\section{Results}

\subsection{Physical Characterization}

The EDX composition of the Pt/GNS, Pt/N-GNP, and Pt/C electrocatalysts is shown in Table 1: the metal content of all the catalysts was in a very good agreement with the nominal composition $(20 \mathrm{wt} \% \mathrm{Pt})$. To evaluate the Pt content and the thermal stability, a thermogravimetric analysis (TGA) was carried out on all the catalysts. TGA curves of Pt/GNS, Pt/N-GNP, and Pt/C catalysts are shown in Figure 1. As reported by Avcioglu et al. [33] for $\mathrm{Pt} / \mathrm{C}$, these curves can be separated into three regions with increasing temperature. The first region is related to the removal of water and volatile species. The second region, where a remarkable weigh loss takes place, is related to Pt catalyzed carbon oxidation. The third region, doesn't present weight loss, and the constant weight represents the amount of $\mathrm{Pt}$. In the absence of platinum, carbon black and graphene have similar thermal stability [34]. In Pt presence the carbon oxidation occurs at lower temperatures.

Table 1. Pt mass by Dispersive Energy (EDX) and thermogravimetric analysis (TGA) measurements, Pt lattice parameter and crystallite size by XRD analysis, and Pt particle size by Transmission Electronic Microscopy (TEM) micrographs of Pt/C, Pt/GNS, and Pt/N-GNP( $\mathrm{d}_{\mathrm{n}}$ : number averaged particle size and $\mathrm{d}_{\mathrm{G}}$ : average Gaussian Pt particle size).

\begin{tabular}{cccccccccc}
\hline Catalyst & $\begin{array}{c}\text { Pt Mass } \\
\text { (EDX)/\% }\end{array}$ & $\begin{array}{c}\text { Pt Mass } \\
\text { (TGA)/\% }\end{array}$ & $\begin{array}{c}\text { Lattice } \\
\text { Parameter/nm }\end{array}$ & $\begin{array}{c}\text { Crystallite Size } \\
\text { (XRD)/nm }\end{array}$ & \multicolumn{3}{c}{$\begin{array}{c}\text { Particle Size (TEM)/nm } \\
\text { As-Prepared Cycled }\end{array}$} \\
\cline { 6 - 10 } & & & & & $\mathbf{d}_{\mathbf{n}}$ & $\mathbf{d}_{\mathbf{G}}$ & $\mathbf{d}_{\mathbf{n}}$ & $\mathbf{d}_{\mathbf{G}}$ \\
$\mathrm{Pt} / \mathrm{C}$ & 20.0 & 17.5 & 0.3888 & 2.2 & $1.9 \pm 0.2$ & 1.9 & $3.6 \pm 1.2$ & 2.8 \\
$\mathrm{Pt} / \mathrm{GNS}$ & 18.6 & 19.4 & 0.3913 & 1.9 & $2.3 \pm 0.4$ & 2.0 & $3.4 \pm 1.7$ & 3.3 \\
$\mathrm{Pt} / \mathrm{N}-\mathrm{GNP}$ & 21.6 & 23.1 & 0.3916 & 3.1 & $2.3 \pm 0.2$ & 2.3 & $4.0 \pm 1.1$ & 3.9 \\
\hline
\end{tabular}

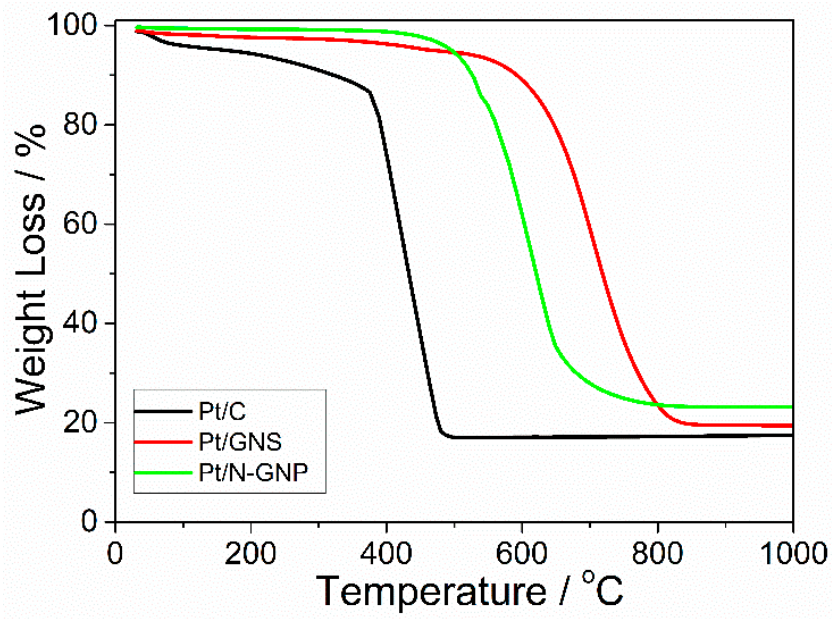

Figure 1. Thermogravimetric analyses of $\mathrm{Pt} / \mathrm{C}, \mathrm{Pt} / \mathrm{GNS}$ and $\mathrm{Pt} / \mathrm{N}-\mathrm{GNP}$ catalysts. The measurements were performed in air atmosphere up to $1000{ }^{\circ} \mathrm{C}$ with a heating ramp of $10{ }^{\circ} \mathrm{C} \mathrm{min}-1$. Abbreviations: GNS, graphene nanosheets; GNP, graphene nanoplatelets. 
For $\mathrm{Pt} / \mathrm{GNs}$, the carbon oxidation occurred between 555 and $840{ }^{\circ} \mathrm{C}$, at higher temperatures than $\mathrm{Pt} / \mathrm{C}$ (between 370 and $485^{\circ} \mathrm{C}$ ), in agreement with the results of Chiang et al. [34]: the deposition of Pt nanoparticles on GNS slightly decreased its resistance to oxidation, but the deposition of Pt nanoparticles on the Vulcan carbon significantly decreased its resistance to oxidation. The functionalization of graphene decreases its thermal stability, thus the carbon oxidation in the presence of $\mathrm{Pt}$ lies between that of carbon black and that of pristine graphene. As can be seen in Table 1, the Pt content in the catalysts by TGA measurements was in an acceptable agreement with that obtained by EDX analysis.

The XRD patterns of the the Pt/GNS, Pt/N-GNP, and Pt/C electrocatalysts are shown in Figure 2. All the patterns show the characteristic peaks of the face centered cubic (fcc) crystalline Pt. In addition, the large sharp peak at $26^{\circ}$ and the smaller peaks at $2 \theta$ values around. $44.5^{\circ}, 54.5^{\circ}, 77^{\circ}$, and $83.5^{\circ}$ in $\mathrm{Pt} / \mathrm{GNS}$ and Pt/N-GNP are related to the (002), (10), (004), (11), and (006) reflexions of nanographene [35,36]. The first broad peak of catalysts at a $2 \theta$ value of around $25^{\circ}$ is ascribed to carbon support. The values of the lattice parameter (a) are reported in Table 1. The lattice parameter of $\mathrm{Pt} / \mathrm{C}$ was lower than that of $\mathrm{Pt} / \mathrm{GNS}$, $\mathrm{Pt} / \mathrm{N}-\mathrm{GNP}$ as it decreases nonlinearly with decreasing the particle size [37]. The average crystallite sizes of the Pt/GNS, Pt/N-GNP, and Pt/C electrocatalysts were evaluated using Scherrer's equation (see Table 1).

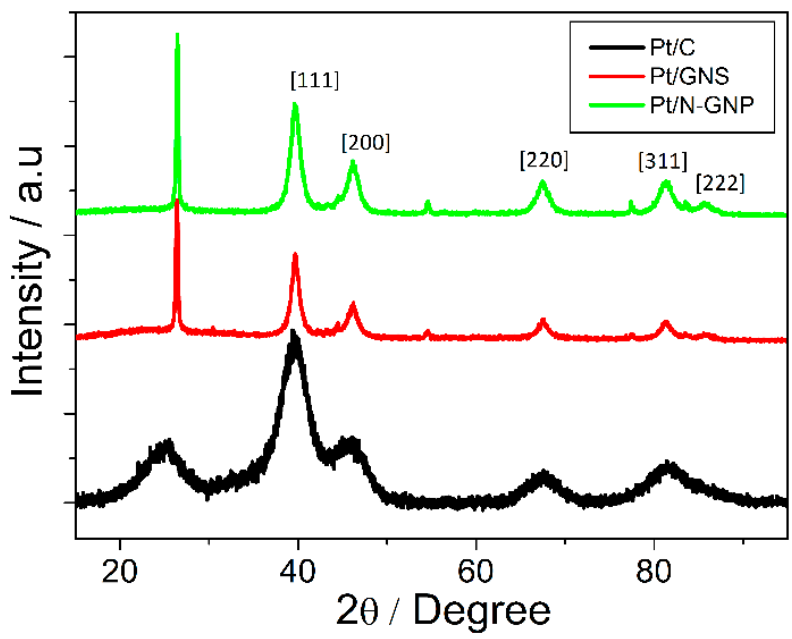

Figure 2. The $\mathrm{X}$-ray diffraction technique (XRD) patterns of $\mathrm{Pt} / \mathrm{C}, \mathrm{Pt} / \mathrm{GNS}$, and $\mathrm{Pt} / \mathrm{N}-\mathrm{GNP}$ catalysts.

To determine the oxidation states of Pt, XPS (X-ray Photon Spectroscopy) analysis was carried out on the Pt/GNS, Pt/N-GNP, and Pt/C electrocatalysts. The XPS patterns of the Pt $4 f$ region are shown in Figure 3a. The Pt $4 f$ XPS signals have two peaks corresponding to the $4 f_{5 / 2}$ and $4 f_{7 / 2}$ states, which have been deconvoluted into three different $\mathrm{Pt}$ oxidation states $\left(\mathrm{Pt}^{0}, \mathrm{Pt}^{2+}\right.$, and $\mathrm{Pt}^{4+}$ oxidation states), the percentage of $\mathrm{Pt}$ oxidation states in the different catalysts is shown in Table 2. The amount of platinum metal $\left(\mathrm{Pt}^{0}\right)$ in graphene and $\mathrm{N}$-doped graphene-supported Pt was higher than that in carbon black-supported Pt. Moreover, XPS measurements were carried out to analyze the N configurations in nitrogen-doped graphene. The XPS pattern of the $\mathrm{N} 1 s$ region of the Pt/N-GNP electrocatalyst is shown in Figure 3b.

The presence of nitrogen atoms into carbon lattice gives rise to three main kinds of nitrogen functional groups, that are pyridinic N, pyrrolic N, and graphitic (quaternary) N species [16]. The N1s spectrum can be de-convoluted to three individual peaks, which represent three nitrogen configurations within carbon structures, Figure 3. The binding energy centered at ca. $398.3 \mathrm{eV}, 399.8 \mathrm{eV}$, and $401.8 \mathrm{eV}$ can be assigned to the pyridinic $\mathrm{N}$, pyrrolic $\mathrm{N}$, and graphitic $\mathrm{N}$, respectively. The relative amount of the $\mathrm{N}$ configurations is reported in Table 2 . The N/C value by XPS measurements was 0.007 . 

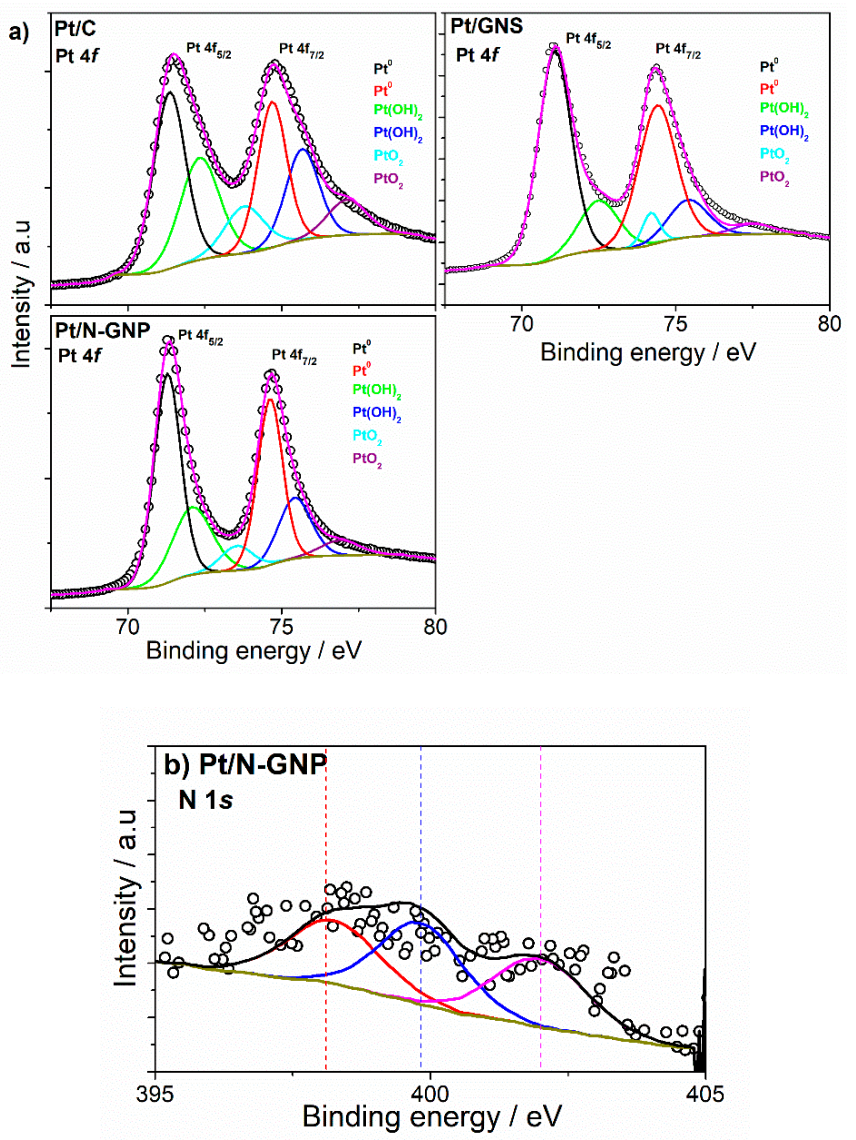

Figure 3. XPS (X-ray Photon Spectroscopy) spectra of (a) Pt $4 f$ of Pt/C, Pt/GNS, and Pt/N-GNP catalysts and (b) Pt/N-GNP N 1s.

Table 2. Amount of Pt $4 \mathrm{f}$ and $\mathrm{N}$ 1s oxidation states (at \%) in Pt/C, Pt/GNS, and Pt/N-GNP by XPS analysis.

\begin{tabular}{ccccccc}
\hline \multirow{2}{*}{ Catalyst } & \multicolumn{3}{c}{$\mathbf{P t}_{\mathbf{4}} \mathbf{7}_{\mathbf{2}}$} & \multicolumn{3}{c}{$\mathbf{N} 1 \mathbf{s}$} \\
\cline { 2 - 7 } & $\mathbf{P t}^{\mathbf{0}}$ & $\mathbf{P t}^{\mathbf{2 +}}$ & $\mathbf{P t}^{\mathbf{4 +}}$ & Pyridinic & Pyrrolic & Graphitic \\
\hline $\mathrm{Pt} / \mathrm{C}$ & 49.21 & 34.80 & 15.99 & - & - & - \\
$\mathrm{Pt} / \mathrm{GNS}$ & 63.96 & 26.14 & 9.89 & - & - & - \\
$\mathrm{Pt} / \mathrm{N}-\mathrm{GNP}$ & 60.79 & 30.78 & 8.43 & 31.0 & 35.5 & 33.5 \\
\hline
\end{tabular}

Figure $4 \mathrm{a}-\mathrm{c}$ reports TEM images and the histograms of the particle size distribution of the as-prepared $\mathrm{Pt} / \mathrm{C}, \mathrm{Pt} / \mathrm{GNS}$, and Pt/N-GNP electrocatalysts. As shown in Figure 4, Pt particles are homogeneously placed on the support, with small agglomeration on Pt/GNS and Pt/N-GN. The histograms of Pt/C and Pt/N-GN particle size are well represented by Gaussian fitting. Conversely, the particle size histogram of the Pt/GNS catalyst showed a slightly asymmetrical distribution, with a tail in the larger particle size region. As shown in Figure 4d-f, following RPC (Repetitive potential cycling) an increase in the particle size and a wider particle size distribution can be observed for all the catalysts. After cycling, the particle size histograms of $\mathrm{Pt} / \mathrm{GNS}$ and Pt/N-GN are well represented by a Gaussian fitting, while the particle size histogram of the $\mathrm{Pt} / \mathrm{C}$ goes from a symmetrical to an asymmetrical distribution, with a tail in the larger particle size region. The values of the average Gaussian Pt particle size $\left(\mathrm{d}_{\mathrm{G}}\right)$ of Pt/GNS, Pt/N-GNP, and Pt/C are reported in Table 1 . The number averaged particle size $\left(d_{n}\right)$ have been calculated using Equation $(1)$ : 


$$
\mathrm{d}_{\mathrm{n}}=\Sigma_{\mathrm{k}} \mathrm{n}_{\mathrm{k}} \mathrm{d}_{\mathrm{k}} / \Sigma_{\mathrm{k}} \mathrm{n}_{\mathrm{k}}
$$

where $n_{k}$ is the frequency of occurrence of particles with size $d_{k}$. The values of $d_{n}$ are reported in Table 1 . The Pt/GNS and Pt/N-GNP present the same value of $d_{n}$. The $\left(d_{n}{ }^{R P C}-d_{n}{ }^{0}\right) / d_{n}{ }^{0}$ ratio, where $d_{n}{ }^{R P C}$ and $d_{n}{ }^{0}$ are the particle size after and before cycling, respectively, indicates the sintering resistance of Pt particles, being the sintering resistance as higher as the lower value of the $\left(d_{n}{ }^{R P C}-d_{n}{ }^{0}\right) / d_{n}{ }^{0}$ ratio. For Pt/GNS, the value of the $\left(\mathrm{d}_{\mathrm{n}}{ }^{\mathrm{RPC}}-\mathrm{d}_{\mathrm{n}}{ }^{0}\right) / \mathrm{d}_{\mathrm{n}}{ }^{0}$ ratio (0.48) was the lowest, followed by that of Pt/N-GNP (0.74) and that of $\mathrm{Pt} / \mathrm{C}(0.89)$. This result does not agree with the theoretical calculations previously reported, reporting higher stability of Pt/N-GNS than Pt/GNS. To support this result there is a work of Naumov et al. [38], which evaluated the stability of nitrogen-doped graphene flakes with theoretical and experimental techniques. They supposed that nitrogen dopants in the graphene sheet interact with $\mathrm{H}^{+}$at the electrode-electrolyte interface, leading to $\mathrm{NH}_{3}$ scission with the formation of vacancies. $\mathrm{N}$ loss and vacancy formation make Pt particles prone to ripening. This could explain the lower structural stability of $\mathrm{Pt} / \mathrm{N}-\mathrm{GNP}$ than that of Pt/GNS. Moreover, the low stability of N-GNP could be due to the presence of a too high nitrogen content [39]. The difference between $\mathrm{d}_{\mathrm{G}}$ and $\mathrm{d}_{\mathrm{n}}$ is an index of the distribution asymmetry. The asymmetry increases with increasing the $A_{G}=\left(d_{n}-d_{G}\right) / d_{n}$ value from 0 to 1 . The low value of $A_{G}$ for $\mathrm{Pt} / \mathrm{C}$ indicates a uniform particle size distribution. After $\mathrm{RPC}$, the $\mathrm{Pt} / \mathrm{C}$ catalyst showed a $\mathrm{A}_{\mathrm{G}}$ value (0.22) remarkably higher than that Pt/GNS (0.029) and Pt/N-GNP (0.025). Summarizing, the Pt/C catalyst showed a lower structural stability than Pt/GNS and Pt/N-GNP, having a lower sintering resistance and a higher asymmetry than graphene-supported catalysts.

As-prepared
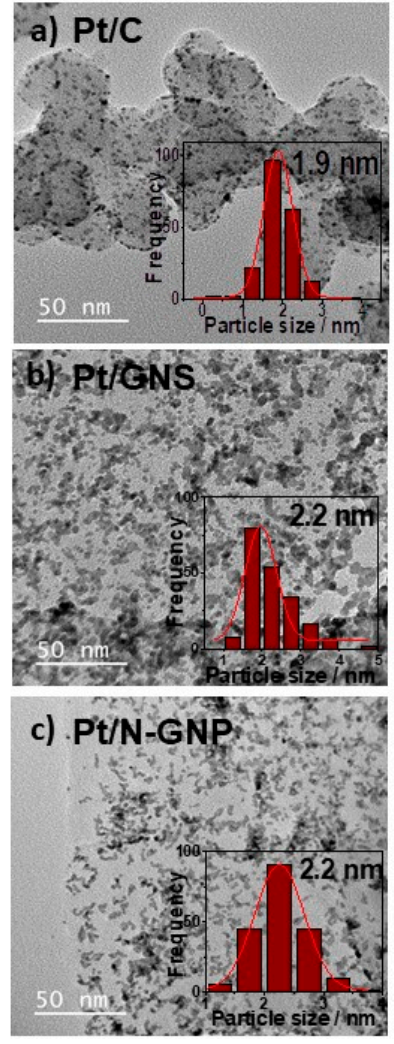

After RPC
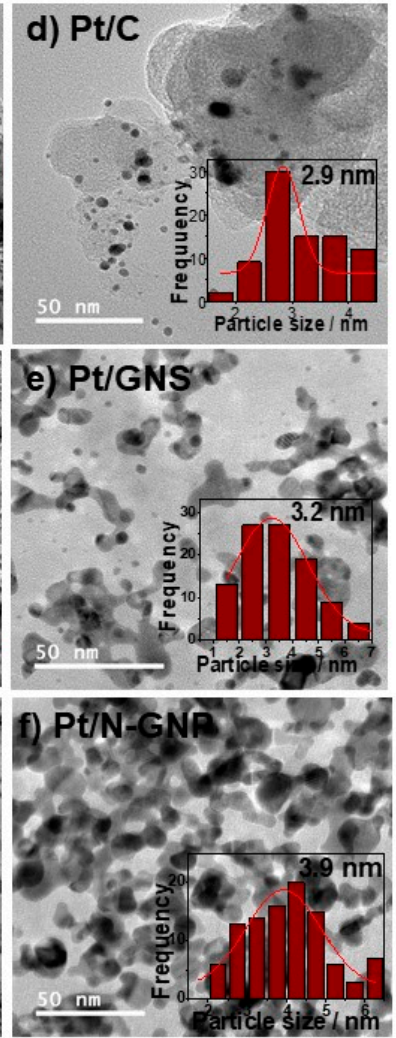

Figure 4. TEM micrographs and histograms of: (a) Pt/C; (b) Pt/GNS, (c) Pt/N-GNP, (d) Pt/C(RPC), (e) Pt/GNS, and (f) $\mathrm{Pt} / \mathrm{N}-\mathrm{GNP}(\mathrm{RPC})$. 


\subsection{Electrochemical Characterization}

CO stripping measurements were carried out to evaluate the catalytic activity for $\mathrm{CO}$ oxidation and to determine the electrochemically active surface area (ECSA). The CO oxidation curves of as-prepared and cycled $\mathrm{Pt} / \mathrm{C}, \mathrm{Pt} / \mathrm{GNS}$, and $\mathrm{Pt} / \mathrm{N}-\mathrm{GNP}$ are shown in Figure 5a-c, respectively. The shape of the CO stripping curves before RPC of Pt/GNS and Pt/N-GNP was different than that of Pt/C: the CO stripping curve of Pt/C presented only one peak with a value of the onset potential of $0.69 \mathrm{~V}$ vs. RHE and a maximum at ca. $0.76 \mathrm{~V}$ vs. RHE, whereas those of Pt/GNS and Pt/N-GNP were characterized by the overlapping of two peaks with the onset potential at 0.58 and $0.35 \mathrm{~V}$ vs. RHE, respectively, and two maxima at 0.67 and $0.70 \mathrm{~V}$ vs. RHE for Pt/GNS and $0.65 \mathrm{~V}$ and $0.68 \mathrm{~V}$ vs. RHE for Pt/N-GNP. The different CO peak potential between carbon black-supported $\mathrm{Pt}$ and graphene-supported $\mathrm{Pt} / \mathrm{C}$ has to be ascribed to the different $\mathrm{CO}$ binding energy. The change of the electronic structure of some $\mathrm{Pt}$ atoms near to $\mathrm{N}$ atoms account for multiple $\mathrm{CO}$ oxidation peaks. These results indicate a higher ability for $\mathrm{CO}$ oxidation of $\mathrm{Pt} / \mathrm{N}-\mathrm{GNP}$ than that of $\mathrm{Pt} / \mathrm{C}$. After RPC, for $\mathrm{Pt} / \mathrm{C}$ a minor peak appeared at lower potential while the main peak shifted to slightly higher potential with reduced intensity, whereas the CO stripping curves of Pt/GNS and Pt/N-GNP didn't change the shape, but reduced their intensity. The electrochemically active surface areas (ECSAs) of Pt/C, Pt/GNS, and $\mathrm{Pt} / \mathrm{N}-\mathrm{GNP}$ were evaluated from the $\mathrm{CO}_{\mathrm{ad}}$ oxidation charge (see Table 3 ).

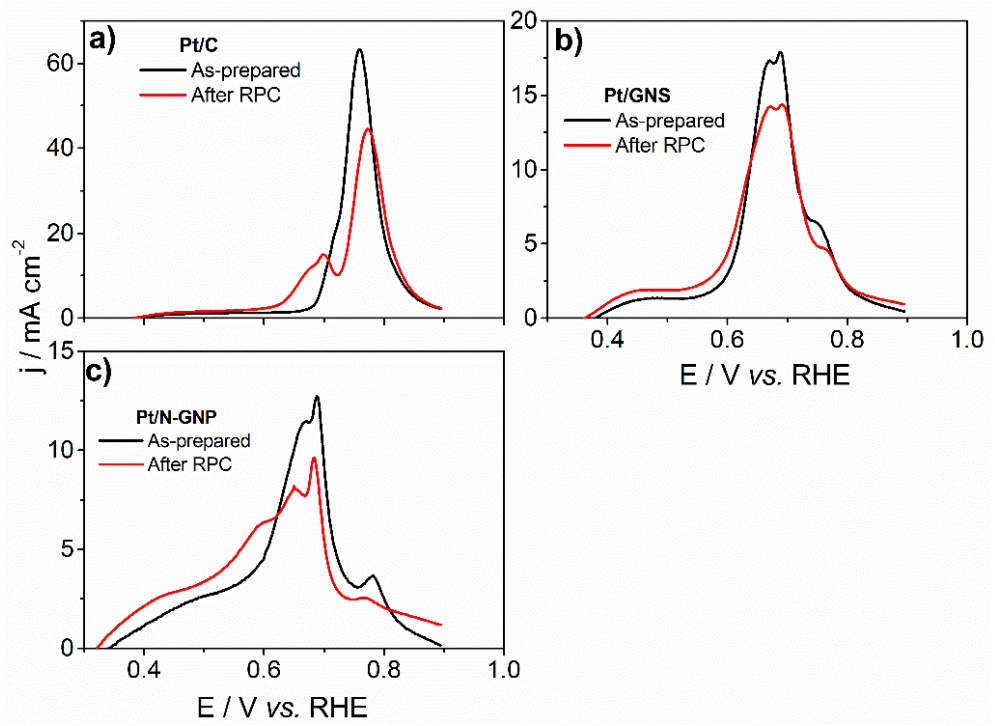

Figure 5. CO oxidation on as-prepared and cycled Pt/C (a), Pt/GNS (b), and Pt/N-GNP (c).

Table 3. Electrochemically active surface area (ECSA) values ECSA loss after RPC of Pt/C, Pt/GNS, and $\mathrm{Pt} / / \mathrm{N}-\mathrm{GNP}$.

\begin{tabular}{cccc}
\hline Catalyst & $\begin{array}{c}\text { ECSA before RPC } \\
\mathbf{c m}^{\mathbf{2}} \mathbf{g}^{-\mathbf{1}}\end{array}$ & $\begin{array}{c}\text { ECSA after RPC } \\
\mathbf{c m}^{\mathbf{2}} \mathbf{g}^{\mathbf{- 1}}\end{array}$ & $\begin{array}{c}\text { ECSA Loss } \\
\mathbf{\%}\end{array}$ \\
\hline $\mathrm{Pt} / \mathrm{C}$ & 66.0 & 61.9 & 6.2 \\
\hline $\mathrm{Pt} / \mathrm{GNS}$ & 32.9 & 32.2 & 2.2 \\
\hline $\mathrm{Pt} / \mathrm{N}-\mathrm{GNP}$ & 25.4 & 24.9 & 1.9 \\
\hline
\end{tabular}

The lower ECSA of $\mathrm{Pt} / \mathrm{GNS}$ and $\mathrm{Pt} / \mathrm{N}-\mathrm{GNP}$ than that of $\mathrm{Pt} / \mathrm{C}$ could be partially ascribed to their slightly larger particle size, but perhaps should be attributed to Pt particle agglomeration, in agreement with TEM analysis. The same result, that is, a similar particle size but a lower ECSA 
for graphene-based-supported Pt than carbon black-supported Pt, was observed by Arteaga et al. [40], and was ascribed to Pt agglomeration. After ageing test, a decrease of the ECSA was observed, owing to particle growth and Pt loss. The decrease of the ECSA, however, was lower than that expected on the basis of the degree of particle growth, likely due to a counteracting cleaning effect by RPC. The ECSA loss of $\mathrm{Pt} / \mathrm{GNS}$ and Pt/N-GNP following RPC was lower than that of Pt/C (Figure 5 and Table 3), indicating a higher stability of graphene and $\mathrm{N}$-graphene-supported catalysts.

Polarization measurements of PEMFCs with $\mathrm{H}_{2}$ and $\mathrm{H}_{2}$ containing $100 \mathrm{ppm} \mathrm{CO}$, with $\mathrm{Pt} / \mathrm{C}, \mathrm{Pt} / \mathrm{GNS}$ and $\mathrm{Pt} / \mathrm{N}-\mathrm{GNP}$ were carried out, as shown in Figure 6a. in the presence of $\mathrm{CO}$ the performance of all the cells decreased, owing to $\mathrm{CO}$ adsorption on Pt sites, hindering $\mathrm{H}_{2}$ adsorption. The PEMFC performance, without $\mathrm{CO}$, depends little on the type of support for current densities up to $0.5 \mathrm{~mA} \mathrm{~cm}{ }^{-2}$, in the order $\mathrm{Pt} / \mathrm{C}>\mathrm{Pt} / \mathrm{N}-\mathrm{GNP}>\mathrm{Pt} / \mathrm{GNS}$. At higher current densities a lower performance of the cells with graphene and N-graphene-supported catalysts is observed, due to the lower ECSA. The higher performance of the cell with Pt/N-GNP than that with Pt/GNS both at low and high current densities is due to a positive effect of nitrogen presence on the hydrogen oxidation, as reported by Chadran et al. [41]. In the presence of $\mathrm{CO}$, instead, the cell with Pt/N-GNP showed a better performance than that of the cells with $\mathrm{Pt} / \mathrm{C}$ and $\mathrm{Pt} / \mathrm{GNS}$, resulting from the superior CO tolerance of the N-GNP support. In the absence of graphene functionalization and subnano $\mathrm{Pt}$ particles, the $\mathrm{CO}$ tolerance of graphene-supported $\mathrm{Pt}$ was lower than that of $\mathrm{Pt} / \mathrm{C}$. The order of the performance at $0.5 \mathrm{~mA} \mathrm{~cm}{ }^{-2}$ was Pt/N-GNP $>\mathrm{Pt} / \mathrm{C}>\mathrm{Pt} / \mathrm{GNS}$ (Figure 7).

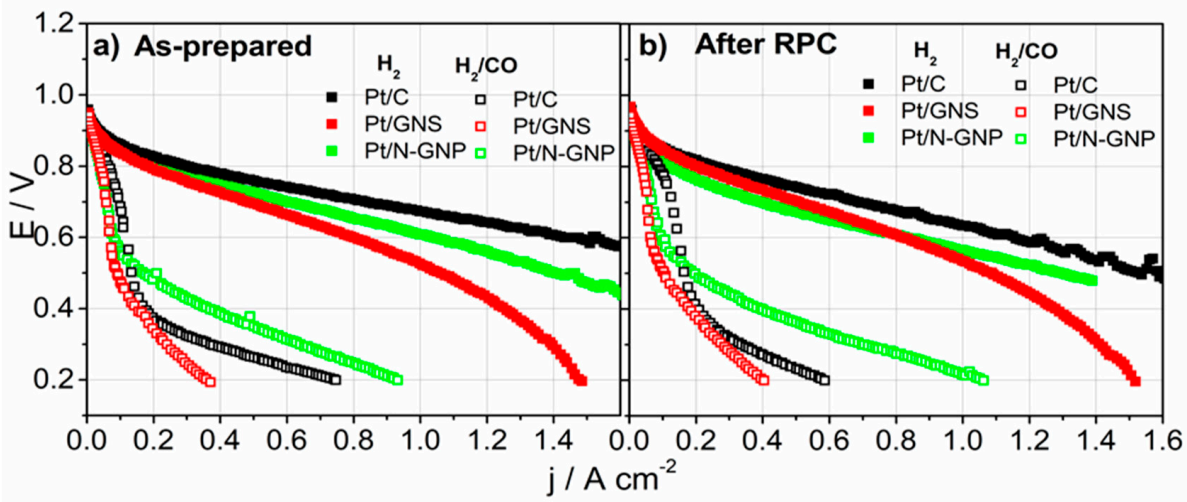

Figure 6. V/j curves of PEMFCs with $\mathrm{Pt} / \mathrm{C}, \mathrm{P} / \mathrm{GNS}$, and $\mathrm{Pt} / \mathrm{N}-\mathrm{GNP}$ fed with $\mathrm{H}_{2}$ (closed symbols) and $\mathrm{H}_{2} / 100$ ppm CO (open symbols) as-prepared (a) and following (b) RPC.

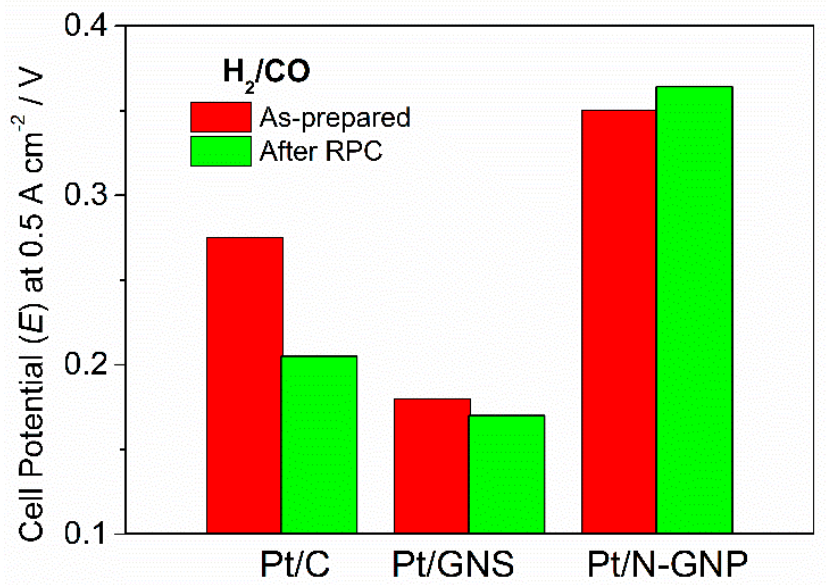

Figure 7. Cell potential at $0.5 \mathrm{~A} \mathrm{~cm}^{-2}$ with Pt/C, Pt/GNS, and Pt/N-GNP as anode materials fed with $\mathrm{H}_{2} / \mathrm{CO}$. 
This experimental result confirms the theoretical studies, indicating that, unlike $\mathrm{CO}$ oxidation on pristine graphene-supported $\mathrm{Pt}$, nitrogen doping in graphene improves $\mathrm{CO}$ tolerance of $\mathrm{Pt}$ nanoparticles. The hydrogen reactivity can be evaluated by the relative occupation ratio $\mathrm{R}$, that is the ratio of adsorption sites occupied by $\mathrm{H}_{2}$ to those occupied by $\mathrm{CO}$ [22]:

$$
\mathrm{R}=\left(\Sigma\left[\mathrm{e}^{\left(\mu \mathrm{H}_{2}-\varepsilon \mathrm{H}_{2}\right) / \mathrm{kT}} /\left(1+\mathrm{e}^{\left(\mu \mathrm{H}_{2}-\varepsilon \mathrm{H}_{2}\right) / \mathrm{kT}}+\mathrm{e}^{(\mu \mathrm{CO}-\varepsilon \mathrm{CO}) / \mathrm{kT}}\right)\right]\right) / \mathrm{N}
$$

where $\mu \mathrm{H}_{2}$ and $\mu \mathrm{CO}$ are the chemical potentials and $\varepsilon \mathrm{H}_{2}$ and $\varepsilon \mathrm{CO}$ are the adsorption energy of hydrogen and carbon monoxide, and $\mathrm{N}$ is the number of available adsorption sites. The $\mathrm{CO}$ tolerance of $\mathrm{Pt}$ nanoparticles increases with increasing $\mathrm{R}$. The higher $\mathrm{CO}$ tolerance of Pt/N-GNP than that of Pt/GNS can be explained by the presence of a defect in graphene generated by N-doping.

Defects in N-doped graphene remarkably enhance Pt binding strength $\left(\mathrm{E}_{\mathrm{b}}\right)$ and lower the average energy of $\mathrm{Pt} d$ electrons ( $d$-band center) ( $\varepsilon \mathrm{dc}$ ) compared to pristine graphene [22]. As previously reported, $\Delta \varepsilon_{\mathrm{ad}}=\left(\varepsilon \mathrm{CO}-\varepsilon \mathrm{H}_{2}\right)$ decreases with increasing $d$-band center of surface Pt atoms $\left(\varepsilon_{\mathrm{dc}}\right)$. Due to $\mathrm{CO}$ adsorption being more sensitive to the $\mathrm{Pt} \mathrm{d}$-band profile than $\mathrm{H}_{2}$ adsorption, a decrease of $\Delta \varepsilon_{\text {ad }}$ is mainly due to the decrease of $\varepsilon \mathrm{CO}$. A decrease of $\varepsilon \mathrm{CO}$ results in an increase of $\mathrm{R}$ (see Equation (2)) and, as a consequence an increase of CO tolerance. Moreover, by EIS measurements it was reported that the incorporated nitrogen atoms induced changes at the Fermi level by opening the band gap of graphene and enhancing the charge transfer, and as a consequence lowering the charge-transfer resistance [42]. This could contribute to the improvement of $\mathrm{CO}$ tolerance.

To assess the electrochemical stability polarization measurements of PEMFCs, fed with $\mathrm{H}_{2}$ and $\mathrm{H}_{2} / \mathrm{CO}$, with aged $\mathrm{Pt} / \mathrm{C}$, Pt/GNS, and Pt/N-GNP were carried out. In the absence of CO, as for as-prepared catalysts, the performance of PEMFC with $\mathrm{Pt} / \mathrm{C}$ was higher than that of $\mathrm{Pt} / \mathrm{GNS}$ and $\mathrm{Pt} / \mathrm{N}-\mathrm{GNS}$ (Figure $6 \mathrm{~b}$ ). Unlike what was observed before RPC, up to $0.9 \mathrm{~A} \mathrm{~cm}^{-2}$ the performance of the cell with Pt/GNS was higher than that with $\mathrm{Pt} / \mathrm{N}-\mathrm{GNP}$, likely due to the higher structural stability of pristine graphene. For current density $>0.9 \mathrm{~A} \mathrm{~cm}^{-2}$, instead, the positive effect of nitrogen presence on the hydrogen oxidation is prevailing, and the performance of the cell with Pt/N-GNP was higher than that with Pt/GNS. As for as-prepared catalysts, for cycled catalysts, in the presence of $\mathrm{CO}$ the performance of the cells with aged catalysts was Pt/N-GNP $>\mathrm{Pt} / \mathrm{C}>\mathrm{Pt} / \mathrm{GNS}$ (Figures $6 \mathrm{~b}$ and 7 ). In the presence of $\mathrm{CO}$, compared to the cell with as-prepared catalysts, after ageing a decrease of the performance of the cell with $\mathrm{Pt} / \mathrm{C}$ as anode catalyst was observed, due to the ECSA decrease by Pt particle growth, whereas the cell with for Pt/GNS and Pt/N-GNP as anode catalyst presented a substantial stability, due to a lower ECSA loss, and, in the case of Pt/N-GNP, to the weaker adsorption of CO on the larger Pt particles [43,44], reducing the poisoning of the catalyst.

The dependence of the anode overpotential $\eta\left(\eta=E_{\mathrm{H}_{2}}-E_{\mathrm{H}_{2} / \mathrm{CO}}\right)$ on the current density for Pt/C, $\mathrm{Pt} / \mathrm{GNS}$, and Pt/N-GNP electrocatalysts before and after RPC is shown in Figure 8 . Both before and after $\mathrm{RPC}$, for current densities $>0.15 \mathrm{~A} \mathrm{~cm}^{-2}$, the overpotential was in the order Pt/N-GNP $<\mathrm{Pt} / \mathrm{C}<\mathrm{Pt} / \mathrm{GNS}$. Following ageing, a decrease of the overpotential for all the catalysts, in particular for Pt/N-GNP, which presents the largest $\mathrm{Pt}$ particle size, can be observed in Figure 8, due to the weaker adsorption of $\mathrm{CO}$ on the larger Pt particles [43,44], reducing the poisoning of the catalyst. At low current density $\left(<0.1 \mathrm{~A} \mathrm{~cm}^{-2}\right)$ following ageing a decrease of the overpotential of the PEMFC with $\mathrm{Pt} / \mathrm{C}$ as the anode catalyst can be observed in Figure 8, while the effect of RPC on the overpotential of the cells with Pt/GNS and Pt/N-GNP was negligible. Conversely for current density $>0.15 \mathrm{~A} \mathrm{~cm}^{-2}$, after RPC a decrease of the overpotential of the PEMFCs with Pt/GNS and, in particular, Pt/N-GNP as the anode catalysts were found, while the overpotential of the cell with $\mathrm{Pt} / \mathrm{C}$ did not change. 


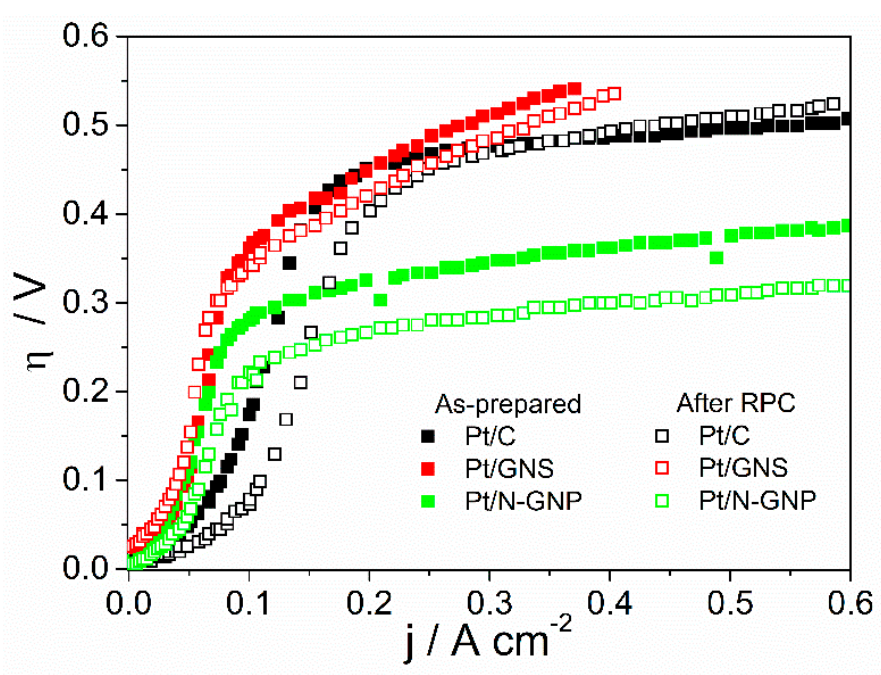

Figure 8. Overpotential vs. current density for Pt/C, Pt/GNS, and Pt/N-GNP catalysts before (closed symbols) and after (open symbols) RPC.

\section{Materials and Methods}

\subsection{Catalyst Preparation}

Graphene nanosheet (GNS) and nitrogen-doped graphene nanoplatelet (N-GNP) (both supplied by Graphene Supermarket $($, Calverton, NY, USA)-supported platinum catalysts $(20 \mathrm{wt} \% \mathrm{Pt})$ were prepared by the ethylene glycol (EG) method in alkaline medium ( $\mathrm{NaOH} 0.1 \mathrm{~mol} \mathrm{~L}{ }^{-1}$ ). $\mathrm{A} \mathrm{H}_{2} \mathrm{PtCl}_{6} \cdot \mathrm{H}_{2} \mathrm{O}$ at $5 \%$ (Aldrich ${ }^{\circledR}$, San Luis, MO, USA) solution was added and mixed with the carbon supports (Vulcan, GNS or N-GNP). Posteriorly this mixture was heated at $150{ }^{\circ} \mathrm{C}$, stirred, and was kept in argon atmosphere under reflux for $6 \mathrm{~h}$. Afterward, the catalyst was neutralized with $\mathrm{HCl} 1.0 \mathrm{~mol} \mathrm{~L}^{-1}$, dispersed into mili- ${ }^{\circledR}$ water, and centrifuged at $5000 \mathrm{rpm}$ for $10 \mathrm{~min}$, this process was repeated four times to assure the cleaning of the supported nanoparticles. Finally, the catalysts were filtered and after was kept for $1 \mathrm{~h}$ under hydrogen atmosphere at $200{ }^{\circ} \mathrm{C}$. Commercial carbon-supported platinum (Pt/C, $\left.20 \mathrm{wt} \%\right)$ by Etek was used as anode catalyst (for comparison with Pt/GNS and Pt/N-GNP) and as cathode catalyst for all experiments.

\subsection{Physical Characterization}

The technique of X-ray Spectroscopy by Dispersive Energy (EDX) was used to obtain the mass ratio between carbon and Pt. The equipment used was a spectrometer (Zeiss-Leica ${ }^{\circledR} 440$ Electron Microscopy Inc., Thornwood, NY, USA) with a SiLi detector. Thermogravimetric analyzes (TGA) were performed on the Mettler Toledo apparatus (Mettler Toledo, Columbus, OH, USA). The conditions used were: temperature range: $30-1000{ }^{\circ} \mathrm{C}$, using synthetic air as a gas at a heating rate of $10^{\circ} \mathrm{C} \mathrm{min}^{-1}$. The X-ray diffraction technique (XRD) was used to determine the structural characteristics of Pt-supported catalysts and to estimate the average sizes of the crystallites. The radiation used was $\mathrm{CuK} \alpha(\lambda=0.15406 \mathrm{~nm})$, generated at $40 \mathrm{kV}$ and $30 \mathrm{~mA}$, in a diffractometer (Rigaku ${ }^{\circledR}$ _ULTIMA IV, Akishima, Tokyo, Japan). The scans were obtained at $1^{\circ} \mathrm{min}^{-1}$ for $2 \theta$ between $10^{\circ}$ and $100^{\circ}$. Using the Transmission Electronic Microscopy (TEM) technique, the average particle size, and distribution for each synthesized catalyst was determined, using a JEOL 2010 microscope (Akishima, Tokyo, Japan) with an energy of $200 \mathrm{keV}$ and a filament of $\mathrm{LaB}_{6}$. X-ray Photon Spectroscopy (XPS, Thermo Scientific K- Alpha spectrometer ${ }^{\circledR}$, Thermo Fischer Scientific, Waltham, MA, USA) using an incident photon energy of $1840 \mathrm{eV}$ (Eph) from an InSb double crystal monochromator (111). The hemispheric electron analyzer was programmed to 
pass electrons at an energy of $20 \mathrm{eV}$, with an energy pass of $0.2 \mathrm{eV}$ and an acquisition time of $200 \mathrm{~ms}$. The spectrum of each catalyst was obtained according to the elements that compose it.

\subsection{Electrochemical Measurements}

In order to test their electrochemical behavior, $\mathrm{Pt} / \mathrm{GNS}, \mathrm{PT} / \mathrm{N}-\mathrm{GNS}$, and $\mathrm{Pt} / \mathrm{C}$ were used as anode catalysts and $\mathrm{Pt} / \mathrm{C}\left(20 \mathrm{wt} \%\right.$ ) at the cathode, both with $0.4 \mathrm{mg} \mathrm{Pt} \mathrm{cm}^{-2}$, in a single PEMFC, as previously detailed in [27]. To perform the polarization curves, Fuel Cell Technologies work station equipment was utilized in the unit cell configuration (cell temperature: $85{ }^{\circ} \mathrm{C}$ ) with $\mathrm{H}_{2}$ and $\mathrm{H}_{2} / \mathrm{CO}$ in the anode $\left(100 \mathrm{~mL} \mathrm{~min}^{-1}, 2 \mathrm{~atm}\right.$ and $\left.100{ }^{\circ} \mathrm{C}\right)$, and $\mathrm{O}_{2}$ in the cathode $\left(150 \mathrm{~mL} \mathrm{~min}^{-1}, 1.70 \mathrm{~atm}\right.$ and $90{ }^{\circ} \mathrm{C}$ ). Before polarization measurements, the potential applied for $2 \mathrm{~h}$ was $0.7 \mathrm{~V}$ and $0.8 \mathrm{~V}$ for $\mathrm{H}_{2}$ and $\mathrm{H}_{2} / \mathrm{CO}$ respectively. The half-cell configuration was used for the Cyclic voltammetry (CV), CO stripping (SCO), and repetitive potential cyclic (RPC), and the work electrode was the anode with Ar and/or CO (for the SCO), in this case $20 \mathrm{~min}$ of $\mathrm{CO}$ followed by $40 \mathrm{~min}$ of Ar, the cathode was provided with $\mathrm{H}_{2}$ employed as a reference electrode (RHE). The potential range was 0.075 to $0.9 \mathrm{~V}$ for CO stripping measurements. The potential range was 0.075 to $1.20 \mathrm{~V}$ at $20 \mathrm{mV} \mathrm{s}^{-1}$ for $\mathrm{CV}$ tests and 0.075 to $0.70 \mathrm{~V}$ at $50 \mathrm{mV} \mathrm{s}^{-1}$ for RPC used as the ageing test, applying 5000 cycles. The protocols used for CV, SCO, and RPC were detailed in Supplementary Materials.

\section{Conclusions}

The structural stability and the activity for hydrogen oxidation in the absence and in the presence of $\mathrm{CO}$ of pristine and nitrogen functionalized graphene-supported Pt electrocatalyst was utilized as anodes in PEMFCs. In the absence of N-functionalization, pristine graphene-supported Pt presents a higher structural stability but a lower CO tolerance than that of the carbon black-supported Pt. N-functionalization of graphene decreases its structural stability but remarkably improves its $\mathrm{CO}$ tolerance. The higher $\mathrm{CO}$ tolerance of $\mathrm{Pt} / \mathrm{N}-\mathrm{GNP}$ than that of $\mathrm{Pt} / \mathrm{GNS}$ was ascribed to the presence of a defect in graphene, generated by $\mathrm{N}$-doping, decreasing $\mathrm{CO}$ adsorption energy. The results of this experimental work, showing that the CO tolerance of graphene is strictly related to its functionalization, confirm the theoretical studies.

Supplementary Materials: The following are available online at http://www.mdpi.com/2073-4344/10/6/597/s1, The protocols used for CV, SCO, and RPC.

Author Contributions: Performed the experiments, M.G.-H.; methodogy, M.G.-H., J.P.; data curation, M.G.-H., J.P., and E.A.; writing-original draft preparation, M.G.-H., J.P., and E.A. All authors have read and agreed to the published version of the manuscript.

Funding: This research was funded by São Paulo Research Foundation (FAPESP) (grant\#2013/16930-7), CNPq (grant\#313286/2018-3) and Coordenação de Aperfeiçoamento de Pessoal de Nível Superior-Brasil (CAPES) -Finance Code 1480786-Capes Proex.

Acknowledgments: LNNano for assisting with the XPS measurements (Project XPS-21416).

Conflicts of Interest: The authors declare no conflicts of interest.

\section{References}

1. Wee, J.-H.; Lee, K.-Y. Overview of the development of CO-tolerant anode electrocatalysts for proton-exchange membrane fuel cells. J. Power Sources 2006, 157, 128-135. [CrossRef]

2. Urian, R.C.; Gullá, A.F.; Mukerjee, S. Electrocatalysis of reformate tolerance in proton exchange membranes fuel cells: Part I. J. Electroanal. Chem. 2003, 554-555, 307-324. [CrossRef]

3. Narischat, N.; Takeguchi, T.; Mori, T.; Iwamura, S.; Ogino, I.; Mukai, S.R.; Ueda, W. Effect of the mesopores of carbon supports on the $\mathrm{CO}$ tolerance of $\mathrm{Pt}_{2} \mathrm{Ru}_{3}$ polymer electrolyte fuel cell anode catalyst. Int. J. Hydrogen Energy 2016, 41, 13697-13704. [CrossRef] 
4. Ehteshami, S.M.M.; Chan, S.H. A review of electrocatalysts with enhanced CO tolerance and stability for polymer electrolyte membarane fuel cells. Electrochim. Acta 2013, 93, 334-345. [CrossRef]

5. Elezović, N.R.; Gajić-Krstajić, L.M.; Vračar, L.M.; Krstajić, N.V. Effect of chemisorbed CO on MoOx-Pt/C electrode on the kinetics of hydrogen oxidation reaction. Int. J. Hydrogen Energy 2010, 35, 12878-12887. [CrossRef]

6. Gruver, G.A. The Corrosion of Carbon Black in Phosphoric Acid. J. Electrochem. Soc. 1978, 125, 1719. [CrossRef]

7. Kangasniemi, K.; Condit, D.A.; Jarvi, T. Characterization of Vulcan Electrochemically Oxidized under Simulated PEM Fuel Cell Conditions. J. Electrochem. Soc. 2004, 151. [CrossRef]

8. Maass, S.; Finsterwalder, F.; Frank, G.; Hartmann, R.; Merten, C. Carbon support oxidation in PEM fuel cell cathodes. J. Power Sources 2008, 176, 444-451. [CrossRef]

9. Antolini, E. Carbon supports for low-temperature fuel cell catalysts. Appl. Catal. B Environ. 2009, 88, 1-24. [CrossRef]

10. Antolini, E.; Gonzalez, E.R. Ceramic materials as supports for low-temperature fuel cell catalysts. Solid State Ion. 2009, 180, 746-763. [CrossRef]

11. Antolini, E.; Gonzalez, E.R. Polymer supports for low-temperature fuel cell catalysts. Appl. Catal. A Gen. 2009, 365, 1-19. [CrossRef]

12. Antolini, E. Graphene as a new carbon support for low-temperature fuel cell catalysts. Appl. Catal. B Environ. 2012, 123, 52-68. [CrossRef]

13. Heydari, A.; Gharibi, H. Fabrication of electrocatalyst based on nitrogen doped graphene as highly efficient and durable support for using in polymer electrolyte fuel cell. J. Power Sources 2016, 325, 808-815. [CrossRef]

14. Inagaki, M.; Toyoda, M.; Soneda, Y.; Morishita, T. Nitrogen-doped carbon materials. Carbon 2018, 132, $104-140$. [CrossRef]

15. Groves, M.N.; Chan, A.S.W.; Malardier-Jugroot, C.; Jugroot, M. Improving platinum catalyst binding energy to graphene through nitrogen doping. Chem. Phys. Lett. 2009, 481, 214-219. [CrossRef]

16. Miao, H.; Li, S.; Wang, Z.; Sun, S.; Kuang, M.; Liu, Z.; Yuan, J. Enhancing the pyridinic N content of Nitrogen-doped graphene and improving its catalytic activity for oxygen reduction reaction. Int. J. Hydrogen Energy 2017, 42, 28298-28308. [CrossRef]

17. Tian, Y.; Liu, Y.-J.; Zhao, J.-X.; Ding, Y.-H. High stability and superior catalytic reactivity of nitrogen-doped graphene supporting $\mathrm{Pt}$ nanoparticles as a catalyst for the oxygen reduction reaction: A density functional theory study. RSC Adv. 2015, 5. [CrossRef]

18. Holme, T.; Zhou, Y.; Pasquarelli, R.; O'Hayre, R. First principles study of doped carbon supports for enhanced platinum catalysts. Phys. Chem. Chem. Phys. 2010, 12, 9461-9468. [CrossRef]

19. Liu, X.; Sui, Y.; Duan, T.; Meng, C.; Han, Y. Monodisperse Pt atoms anchored on N-doped graphene as efficient catalysts for CO oxidation: A first-principles investigation. Catal. Sci. Technol. 2015, 5, 1658-1667. [CrossRef]

20. He, D.; Jiang, Y.; Lv, H.; Pan, M.; Mu, S. Nitrogen-doped reduced graphene oxide supports for noble metal catalysts with greatly enhanced activity and stability. Appl. Catal. B Environ. 2013, 132, 379-388. [CrossRef]

21. Tang, Y.; Yang, Z.; Dai, X. A theoretical simulation on the catalytic oxidation of CO on Pt/graphene. Phys. Chem. Chem. Phys. 2012, 14, 16566-16572. [CrossRef] [PubMed]

22. Kim, G.; Jhi, S.-H. Carbon Monoxide-Tolerant Platinum Nanoparticle Catalysts on Defect-Engineered Graphene. ACS Nano 2011, 5, 805-810. [CrossRef] [PubMed]

23. Scardamaglia, M.; Bittencourt, C. Metal-free catalysis based on nitrogen-doped carbon nanomaterials: A photoelectron spectroscopy point of view. Beilstein J. Nanotechnol. 2018, 9, 2015-2031. [CrossRef] [PubMed]

24. Krishnan, R.; Su, W.-S.; Chen, H.-T. A new carbon allotrope: Penta-graphene as a metal-free catalyst for CO oxidation. Carbon 2017, 114, 465-472. [CrossRef]

25. Yoo, E.; Okata, T.; Akita, T.; Kohyama, M.; Nakamura, J.; Honma, I. Enhanced Electrocatalytic Activity of Pt Subnanoclusters on Graphene Nanosheet Surface. Nano Lett. 2009, 9, 2255-2259. [CrossRef]

26. Yoo, E.; Okada, T.; Akita, T.; Kohyama, M.; Honma, I.; Nakamura, J. Sub-nano-Pt cluster supported on graphene nanosheets for CO tolerant catalysts in polymer electrolyte fuel cells. J. Power Sources 2011, 196, 110-115. [CrossRef] 
27. González-Hernández, M.; Antolini, E.; Perez, J. CO tolerance and stability of PtRu and PtRuMo electrocatalysts supported on $\mathrm{N}$-doped graphene nanoplatelets for polymer electrolyte membrane fuel cells. Int. J. Hydrogen Energy 2019, 45, 5276-5284. [CrossRef]

28. Çögenli, M.S.; Bayrakçeken Yurtcan, A. Heteroatom doped 3D graphene aerogel supported catalysts for formic acid and methanol oxidation. Int. J. Hydrogen Energy 2020, 45, 650-666. [CrossRef]

29. Liu, C.-S.; Liu, X.-C.; Wang, G.-C.; Liang, R.-P.; Qiu, J.-D. Preparation of Nitrogen-Doped Graphene Supporting Pt Nanoparticles As a Catalyst for Oxygen Reduction and Methanol Oxidation. J. Electroanal. Chem. $2014,728$. [CrossRef]

30. Tao, L.; Dou, S.; Ma, Z.; Shen, A.; Wang, S. Simultaneous Pt deposition and nitrogen doping of graphene as efficient and durable electrocatalysts for methanol oxidation. Int. J. Hydrogen Energy 2015, 40, 14371-14377. [CrossRef]

31. Ma, J.-H.; Wang, L.; Mu, X.; Li, L. Nitrogen-doped graphene supported Pt nanoparticles with enhanced performance for methanol oxidation. Int. J. Hydrogen Energy 2015, 40, 2641-2647. [CrossRef]

32. Xin, Y.; Liu, J.-G.; Jie, X.; Liu, W.; Liu, F.; Yin, Y.; Gu, J.; Zou, Z. Preparation and electrochemical characterization of nitrogen doped graphene by microwave as supporting materials for fuel cell catalysts. Electrochim. Acta 2012, 60, 354-358. [CrossRef]

33. Avcioglu, G.S.; Ficicilar, B.; Bayrakceken, A.; Eroglu, I. High performance PEM fuel cell catalyst layers with hydrophobic channels. Int. J. Hydrogen Energy 2015, 40, 7720-7731. [CrossRef]

34. Chiang, Y.-C.; Liang, C.-C.; Chung, C.-P. Characterization of Platinum Nanoparticles Deposited on Functionalized Graphene Sheets. Materials 2015, 8, 6484-6497. [CrossRef] [PubMed]

35. Popova, A.N. Crystallographic analysis of graphite by X-Ray diffraction. Coke Chem. 2017, 60, 361-365. [CrossRef]

36. Saenko, N.S.; Ziatdinov, A.M. The small-angle $\gamma$-band of the X-ray diffraction for nanographite powder and its approximation by full-profile analysis. Mater. Today Proc. 2018, 5, 26052-26057. [CrossRef]

37. Leontyev, I.N.; Kuriganova, A.B.; Leontyev, N.G.; Hennet, L.; Rakhmatullin, A.; Smirnova, N.V.; Dmitriev, V. Size dependence of the lattice parameters of carbon supported platinum nanoparticles: X-ray diffraction analysis and theoretical considerations. RSC Adv. 2014, 4, 35959-35965. [CrossRef]

38. Naumov, O.; Naumov, S.; Abel, B.; Varga, A. The stability limits of highly active nitrogen doped carbon ORR nano-catalysts: A mechanistic study of degradation reactions. Nanoscale 2018, 10, 6724-6733. [CrossRef]

39. Chaban, V.; Prezhdo, O. Nitrogen-Nitrogen Bonds Violate Stability of N-Doped Graphene. arXiv 2015, arXiv:1502.01939.

40. Arteaga, G.; Rivera-Gavidia, M.L.; Martínez, J.S.; Rizo, R.; Pastor, E.; García, G. Methanol Oxidation on Graphenic-Supported Platinum Catalysts. Surfaces 2019, 2, 16-31. [CrossRef]

41. Chandran, P.; Ghosh, A.; Ramaprabhu, S. High-performance Platinum-free oxygen reduction reaction and hydrogen oxidation reaction catalyst in polymer electrolyte membrane fuel cell. Sci. Rep. 2018, 8, 3591. [CrossRef] [PubMed]

42. Coros, M.; Varodi, C.; Pogacean, F.; Gal, E.; Pruneanu, M.S. Nitrogen-Doped Graphene: The Influence of Doping Level on the Charge-Transfer Resistance and Apparent Heterogeneous Electron Transfer Rate. Sensors 2020, 20, 1815. [CrossRef] [PubMed]

43. Gloaguen, F.; Le'Ger, J.M.; Lamy, C. Electrocatalytic oxidation of methanol on platinum nanoparticles electrodeposited onto porous carbon substrates. J. Appl. Electrochem. 1997, 27, 1052-1060. [CrossRef]

44. Bergamaski, K.; Pinheiro, A.L.N.; Teixeira-Neto, E.; Nart, F.C. Nanoparticle Size Effects on Methanol Electrochemical Oxidation on Carbon Supported Platinum Catalysts. J. Phys. Chem. B 2006, 110, 19271-19279. [CrossRef] [PubMed]

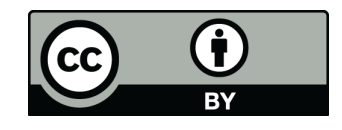

(C) 2020 by the authors. Licensee MDPI, Basel, Switzerland. This article is an open access article distributed under the terms and conditions of the Creative Commons Attribution (CC BY) license (http://creativecommons.org/licenses/by/4.0/). 